\title{
Pozycja kobiet na rynku pracy w świetle regulacji Unii Europejskiej
}

\section{Wprowadzenie}

$\mathbf{U}$ nijne regulacje na poziomie prawa pierwotnego dotyczące stricte określonych grup społecznych funkcjonujących na rynku pracy, zasadniczo koncentrują się wokół kwestii dyskryminacji i mają na celu jej przeciwdziałanie. Dyskryminacja nie jest zjawiskiem nowym. Mając na uwadze różne konotacje pojęcia zależne od przyjętej perspektywy wynikającej z określonej dyscypliny naukowej, zasadniczo można przyjąć, iż jest to nierówne traktowanie konkretnych jednostek albo grup społecznych przez odmawianie im udziału $w$ przywilejach, prestiżu czy władzy, oparte jedynie na nieprzychylnym nastawieniu i uprzedzeniach ze względu na pewne ich rzeczywiste lub domniemane (przeważnie) cechy, np. przynależność klasowa, rasę, płeć, wyznanie ${ }^{1}$. W prawodawstwie polskim definicja dyskryminacji oraz obowiązek równego traktowania kobiet i mężczyzn przez pracodawców pojawiły się ze względu na konieczność dostosowania do regulacji unijnych, natomiast na szczeblu wspólnotowym zakaz dyskryminacji oraz zasada równości stanowią jeden z jej fundamentów.

\section{Regulacje prawne dotyczące sytuacji kobiet na rynku pracy}

Pierwotnych podstaw prawnych w zakresie praw kobiet na rynku pracy należy szukać w Traktatach Rzymskich, w których znalazł się zapis dotyczący konieczności wprowadzenia i stosowania przez państwa członkowskie zasady równości wynagrodzeń dla kobiet i mężczyzn za tę samą pracę ${ }^{2}$. Aktualnie zadaniem UE jest także wspieranie i uzupełnianie państw członkowskich w dziedzinie równości kobiet i mężczyzn w odniesieniu do ich szans na rynku pracy i traktowania $\mathrm{w}$ pracy ${ }^{3}$. Co więcej, jak wskazuje art. 141 TWE $w$ celu zapewnienia petnej równości między mężczyznami i kobietami w życiu zawodowym zasada równości traktowania nie stanowi przeszkody dla Państwa Członkowskiego w utrzymaniu lub przyjmowaniu środków przewidujacych specyficzne korzyści, zmierzajace do ułatwienia wykonywania działalności zawodowej przez osoby ptci niedostatecznie reprezentowanej badź zapobiegania niekorzystnym sytuacjom $w$ karierze zawodowej $i$ ich kompensowania ${ }^{4}$.

\footnotetext{
${ }^{1}$ Hasło ,dyskryminacja” w: K. Olechnicki, P. Załęcki, Słownik socjologiczny, Wydawnictwo Graffiti BC, Toruń 1999, s. 49-50.

${ }^{2}$ Traktat ustanawiający Europejską Wspólnotę Gospodarczą, art. 119.

${ }^{3}$ Traktat ustanawiający Wspólnotę Europejską - wersja skonsolidowana (Dz. U. C 321E z 29 grudnia 2006), art. 137.

${ }^{4}$ Ibidem, art. 141.
} 
Zagadnienia tego dotyczą także pośrednio przepisy natury ogólnej zaliczające do zadań Wspólnoty popieranie wysokiego poziomu zatrudnienia i ochrony socjalnej, a także równości kobiet i mężczyzn ${ }^{5}$. Ponadto działalność UE wedle postanowień Traktatu ustanawiającego Wspólnotę Europejską nakierowana jest na zniesienie nierówności i zarazem promowanie równości kobiet i mężczyzn ${ }^{6}$. W tym też celu w 1981 r. powołano Komitet Doradczy ds. Równości Szans Kobiet i Mężczyzn, którego głównym zadaniem jest wspieranie Komisji Europejskiej w przygotowywaniu i realizacji działań podejmowanych na rzecz równości płci ${ }^{7}$. Rada Unii Europejskiej zyskała ponadto możliwość podejmowania określonych środków w obszarze zwalczania wszelkich form dyskryminacji, w tym ze względu na płeć, czego wyraz stanowi zapis art. 13 TWE.

Zasada równego traktowania kobiet i mężczyzn, mająca swoją podstawę w traktatach, znalazła wyraz w kilku dyrektywach, które stanowią dla niej rozwinięcie. Dotyczą one zasadniczo następujących obszarów:

— równości w wynagrodzeniu ${ }^{8}$;

— równości w dostępie do rynku pracy;

— równych uprawnień do zabezpieczenia społecznego ${ }^{9}$;

— urlopów macierzyńskich;

— urlopów rodzicielskich ${ }^{10}$;

— zdrowia i bezpieczeństwa;

— pracy w mniejszym wymiarze;

- ciężaru dowodów.

Wraz ze zwiększonym zainteresowaniem na poziomie unijnym kwestiami polityki społecznej oraz wpływu warunków socjalnych na wzrost gospodarczy, w prawodawstwie wspólnotowym dostrzeżono potrzebę szczegółowszego uregulowania kwestii równego traktowania kobiet i mężczyzn na rynku pracy, wyrazem czego jest chociażby dyrektywa Rady z dnia 9 lutego 1976 r. w sprawie wprowadzenia w życie zasady równego traktowania kobiet i mężczyzn w zakresie dostępu do zatrudnienia, kształcenia i awansu zawodowego oraz warunków pracy, w której art. 2 zasadę równego traktowania zdefiniowano jako brak dyskryminacji ze względu na płeć, tak bezpośredniej, jak i pośredniej, w szczególności przez odniesienie się do stanu cywilnego lub rodzinnego ${ }^{11}$. Dyrektywa ta została następnie zmieniona dyrektywą Parlamentu Europejskiego i Rady z dnia 23 września 2002 r. ${ }^{12}$, która znacznie poszerzyła rozumienie po-

\footnotetext{
5 Ibidem, art. 2 .

${ }^{6}$ Ibidem, art. 3 .

${ }^{7}$ Komitet został powołany na mocy decyzji Komisji z dnia 9 grudnia 1982 r. w sprawie utworzenia Komitetu Doradczego ds. Równości Szans dla Kobiet i Mężczyzn (Dz. U. nr L 20 z 28.01.1982, s. 35-37).

${ }^{8}$ Dyrektywa Rady 75/117/EWG z dnia 10 lutego 1975 r. w sprawie zbliżenia ustawodawstw Państw Członkowskich dotyczqcych stosowania zasady równości wynagrodzeń dla mężczyzn i kobiet (Dz. U. WE nr L 45, z 19.02.1975, s. 19).

${ }_{9}$ Dyrektywa Rady 79/7/EWG z 19 grudnia 1978 r. w sprawie stopniowego wprowadzania wżycie zasady równego traktowania kobiet i mężczyzn w dziedzinie zabezpieczenia społecznego (Dz. U nr L 6 z 10.01.1979, s. 24; polskie wydanie specjalne: Rozdział 05, tom 01, s. 254-256).

${ }^{10}$ Dyrektywa Rady 96/34/WE z dnia 3 czerwca 1996 r. w sprawie porozumienia ramowego dotyczacego urlopu rodzicielskiego zawartego przez UNICE, CEEP oraz ETUC (Dz. U. nr L 145 z 19.06.1996, s. 4).

${ }^{11}$ Dyrektywa Rady (76/207/EWG) z dnia 9 lutego 1976 r. w sprawie wprowadzenia w życie zasady równego traktowania kobiet i mężczyzn w zakresie dostępu do zatrudnienia, kształcenia i awansu zawodowego oraz warunków pracy (Dz. U. WE nr L 39 z 14.2.1976, s. 40).

${ }^{12}$ Dyrektywa Parlamentu Europejskiego i Rady 2002/73/WE z dnia 23 września 2002 r. zmieniająca dyrektywę Rady 76/207/EWG w sprawie wprowadzenia w życie zasady równego traktowania mężczyzn i kobiet w zakresie dostępu do zatrudnienia, kształcenia i awansu zawodowego oraz warunków pracy (Dz. U. L 269 z 5.10.2002, s. 15).
} 
jęcia dyskryminacji i wprowadziła rozróżnienie na bezpośrednią i pośrednią. Ta pierwsza odnosi się do sytuacji, w której dana osoba traktowana jest mniej korzystnie ze względu na płeć niż jest, była lub bytaby traktowana inna osoba $w$ porównywalnej sytuacji ${ }^{13}$. Za dyskryminację pośrednią uznano natomiast sytuację, w której z pozoru neutralny przepis, kryterium lub praktyka stawiałaby osoby danej płci $w$ szczególnie niekorzystnym położeniu $w$ porównaniu do osób innej ptci, chyba że dany przepis, kryterium lub praktyka sq obiektywnie uzasadnione usankcjonowanym prawnie celem, a środki osiagania tego celu sq właściwe i niezbędne ${ }^{14}$. Ponadto w dyrektywie zdefiniowano także pojęcie molestowania oraz molestowania seksualnego.

\section{Programy i strategie na rzecz równości kobiet i mężczyzn}

Na potrzebę dalszych zmian w zakresie równości kobiet i mężczyzn wskazuje także Komisja Europejska, która w jednym ze swych komunikatów zaprezentowała Plan działań na rzecz równości kobiet i mężczyzn 2006-2010 ${ }^{15}$. W dokumencie tym wyznaczono sześć priorytetowych obszarów, które wymagają podjęcia działań. Zaliczono do nich:

— równą niezależność ekonomiczną kobiet i mężczyzn;

- pogodzenie życia prywatnego i zawodowego;

— równe uczestnictwo w podejmowaniu decyzji;

— wykorzenianie wszelkich form przemocy uwarunkowanej płcią;

- eliminowanie stereotypów związanych z płcią;

— propagowanie równości płci w stosunkach zewnętrznych oraz polityce rozwoju.

W każdym z tych obszarów określono ponadto szczegółowe cele oraz formy ich realiza$\mathrm{cji}^{16}$. Zauważono, iż należy podjąć działania na rzecz zwiększenia zatrudnienia wśród kobiet. Temu celowi miała służyć przede wszystkim dbałość o prawidłowe funkcjonowanie dwóch obszarów, tj. prawodawstwa w dziedzinie równości płci oraz wykorzystania nowych funduszy strukturalnych. W dokumencie odniesiono się także do założeń Strategii Lizbońskiej, wedle której w 2010 r. odsetek kobiet pracujących miał sięgnąć pułapu $60 \%{ }^{17}$. Podkreślono także, iż należy podjąć działania zmierzające do wyrównania płac obojga płci. W połowie I dekady XXI w. średnio kobiety zarabiały o $15 \%$ mniej niż mężczyźni ${ }^{18}$, pomimo istniejącego prawodawstwa UE w zakresie równości ich wynagrodzenia. Tego też obszaru dotyczył komunikat Komisji Europejskiej z dnia 18 lipca 2007, w którym poruszono kwestie przyczyn utrzymywania się takiego stanu rzeczy oraz możliwych sposobów eliminowania tych różnic. Zauważono, że nierówności w wynagrodzeniu uwarunkowane są wieloprzyczynowo i zdecydowanie wykraczają poza ogólną normę postulującą równość wynagrodzenia za

\footnotetext{
${ }^{13}$ Ibidem.

${ }^{14}$ Ibidem.

${ }^{15}$ Komunikat Komisji Europejskiej do Rady, Parlamentu Europejskiego, Europejskiego Komitetu Ekonomiczno-Społecznego oraz Komitetu Regionów, Plan działań na rzecz równości kobiet i mężczyzn 2006-2010, Bruksela, dnia 1 marca 2006, KOM(2006) 92 wersja ostateczna.

${ }^{16}$ Podstawą ich wyznaczenia były doświadczenia Wspólnotowej Strategii Ramowej na rzecz Równości Ptci (2001-2005), COM(2000) 335.

${ }^{17}$ W 2006 r. ogólny poziom zatrudnienia sięgał granicy 55,7\%, jednakże już w przedziale wiekowym 55-64 lata był drastycznie niższy i znajdował się na pułapie 31,7\%. Dostrzegalne różnice widać było także we wskaźniku bezrobocia w zależności od płci. Dla mężczyzn wynosił on 7,8\% dla kobiet zaś 9,7\%.

${ }^{18} \mathrm{Na}$ temat m.in. dyskryminacji płacowej kobiet patrz: B. Kalinowska-Nawrotek, Kobiety na rynku pracy: sytuacja w Polsce na tle krajów Unii Europejskiej, w: Przemiany i perspektywy polskich przedsiębiorstw w dobie integracji z Uniq Europejska, red. K. Piech, G. Szczodrowski, t. 2, Instytut Wiedzy, Warszawa 2003.
} 
taką samą pracę. Jedną z najjaskrawszych determinant tego zjawiska jest dyskryminacja ${ }^{19}$, jednakże równie często powody tej sytuacji nie są tak oczywiste. Jak zauważono, kobiety częściej niż mężczyźni wykonują pracę nieodpłatnie (np. opieka nad dziećmi i prowadzenie domu), częściej także pracują w niepełnym wymiarze godzin. Ponadto niektóre branże zatrudniające w głównej mierze kobiety, znajdują się w dolnej granicy systemu wynagrodzenia. Problem tkwi także w sposobie wartościowania kompetencji. Z reguły stanowiska zajmowane przez kobiety są gorzej opłacane, przy założeniu o konieczności posiadania podobnych kwalifikacji czy też doświadczenia. Nierówności w wynagrodzeniu są tylko elementem szerszego problemu dotyczącego braku równowagi na rynku pracy, której przejawem są także doświadczane przez kobiety trudności w pogodzeniu życia zawodowego i rodzinnego. Kobiety ponadto znacznie rzadziej zajmują stanowiska kierownicze i w karierze zawodowej napotykają więcej trudności, przez co charakteryzuje się ona mniejszą dynamiką. Statystyki wskazują, iż dysproporcja w wynagrodzeniu kobiet i mężczyzn zwiększa się wraz z wiekiem, poziomem wykształcenia i stażem pracy ${ }^{20}$. Celem niwelowania różnic płacowych, Komisja wyznaczyła cztery następujące obszary, które wymagają większego zaangażowania:

— wzrost konsekwencji w stosowaniu istniejących przepisów prawnych;

— rozpatrywanie działań na rzecz zmniejszenia różnic w wynagrodzeniu między kobietami i mężczyznami w kategoriach integralnej części polityki zatrudnienia każdego państwa członkowskiego;

— promowanie równego wynagradzania pracowników, w szczególności poprzez odpowiedzialność społeczną;

— wspieranie wymiany dobrych praktyk oraz pozyskiwanie partnerów społecznych ${ }^{21}$.

Z uwagi na fakt, iż kobiety stanową znacznie niższy odsetek wśród przedsiębiorców w UE, tj. zaledwie 30\%, podkreślono konieczność dalszego wdrażania rozwiązań sprzyjających zwiększeniu ilości przedsięwzięć przez nie podejmowanych. Główne kierunki działań miały obejmować usprawnienie dostępu do dofinansowania oraz rozwój sieci przedsiębiorczości. Za sprawę ważną uznano, by systemy zabezpieczeń społecznych poszczególnych państw członkowskich nakierowane były na zachęcanie zarówno kobiet, jak i mężczyzn do zajmowania i utrzymywania miejsc pracy umożliwiających im gromadzenie indywidualnych uprawnień emerytalnych. Wśród kobiet występuje bowiem większe ryzyko zubożenia, gdyż to one częściej stają wobec konieczności przerwania kariery zawodowej lub jej skrócenia, czego konsekwencją są niższe kwoty świadczeń. Mając powyższe na uwadze wskazano, iż bardzo ważne jest by systemy zabezpieczeń społecznych zapewniły im dostęp do stosownych świadczeń. Odniesiono się także do problemu różnic w potrzebach związanych ze środowiskiem pracy, jakie występują między kobietami i mężczyznami oraz konieczność ich zharmonizowania z tymi wymaganiami. Ponadto podkreślono, iż praktyki stosowane w służbie zdrowia i opieki socjalnej winny być ustawicznie unowocześniane i dostosowywane do specyficznych i nowych potrzeb obojga płci. Jako ważną kwestię uznano również zwielo-

\footnotetext{
${ }^{19}$ Szeroko na temat instrumentów przeciwdziałania dyskryminacji patrz: Równość szans kobiet i mężczyzn a rynek pracy, red. M. Borowska, M. Branka, Centrum Rozwoju Zasobów Ludzkich, Warszawa 2010.

${ }^{20}$ Najwyższe różnice w wynagrodzeniu występują w grupie wiekowej 50-59 lat i sięgają rzędu 30\%. Podobny pułap rozwarstwienia placowego jest osiagany wśród osób z wykształceniem trzeciego stopnia. Natomiast różnice w stawkach wynagrodzenia pracowników z 30-letnim stażem pracy oscylują wokół 32\%.

${ }^{21}$ Komunikat Komisji do Rady, Parlamentu Europejskiego, Europejskiego Komitetu Ekonomiczno-Społecznego i Komitetu Regionów - Znoszenie różnic w wynagradzaniu kobiet i mężczyzn, Bruksela, dnia 18.07.2007, $\operatorname{KOM}(2007) 424$ wersja ostateczna.
} 
krotnioną dyskryminację, której w szczególności doświadczają kobiety z mniejszości etnicznych i grup znajdujących się w niekorzystnej sytuacji, a także imigrantów ${ }^{22}$.

W obszarze godzenia życia rodzinnego i prywatnego z praca, wskazano na problem braku równowagi między płciami w sferze korzystania z możliwości, jakie daje elastyczna organizacja czasu pracy ${ }^{23}$. Pomimo korzyści płynących z tej formy organizacyjnej, z uwagi na fakt, iż w większej mierze uczestniczą w niej kobiety, ma ona negatywny wpływ na postrzeganie ich pozycji oraz finalnie, na ich niezależność finansową. W konkluzji za najważniejsze trzy główne obszary problemowe wspólnotowej polityki społecznej uznano:

- kurczącą się populację osób w wieku produkcyjnym;

- niski wskaźnik urodzeń;

- rosnącą liczbę osób starszych.

Wobec faktu, iż w dalszym ciagu obowiązek opieki nad dziećmi, wraz ze wszystkimi tego konsekwencjami, w głównej mierze spoczywa na kobietach ${ }^{24}$, postuluje się szersze propagowanie wśród mężczyzn korzystania z urlopów rodzicielskich i ojcowskich ${ }^{25}$.

Za równie istotne w „Planie” uznano promowanie równego uczestnictwa kobiet i mężczyzn w podejmowaniu decyzji. W tym obszarze odniesiono się do udziału kobiet w polityce wskazując, iż nadal niedostateczna ich reprezentacja jest wyrazem deficytu demokracji. Postulat zrównoważonego uczestnictwa obu płci wysunięto także w kwestii podejmowania decyzji ekonomicznych, co jak zauważono może przyczynić się do wykreowania efektywniejszego otoczenia zawodowego, a w konsekwencji także wzrostu gospodarczego. Założono również działania mające na celu zwiększenie udziału kobiet w sektorze nauki i technologii, w czym upatruje się źródeł wzrostu innowacyjności, jakości oraz konkurencyjności, w szczególności w obszarze badań ${ }^{26}$. Na wagę czynników społecznych, w tym równości kobiet i mężczyzn na rynku pracy, i ich wpływ na konkurencyjność międzynarodową, wskazują fakty - najwyższe pozycje, jakie w Ogólnoświatowym Rankingu Konkurencyjności zajmują państwa promujące równość płci na rynku pracy ${ }^{27}$.

Na wagę potrzeby zrównoważenia proporcji w ilości kobiet i mężczyzn pełniących stanowiska kierownicze, wskazuje fakt powołania do istnienia w 2008 r. europejskiej sieci na rzecz promowania kobiet na stanowiskach decyzyjnych w polityce i gospodarce, która ma stanowić platformę wymiany dobrych praktyk w skali UE ${ }^{28}$.

\footnotetext{
${ }^{22}$ Plan działań na rzecz równości kobiet i mężczyzn 2006-2010.

${ }^{23}$ Szeroko na temat różnych aspektów związanych z rynkiem pracy kobiet patrz: Godzenie pracy z rodzinq w kontekście aktywizacji zawodowej kobiet, red. C. Sadowska-Snarska, T. Li, Wydawnictwo Wyższej Szkoły Ekonomicznej w Białymstoku, Białystok 2008.

${ }^{24}$ Zaledwie 7,4\% mężczyzn korzysta $\mathrm{z}$ urlopu ojcowskiego lub pracuje w niepełnym wymiarze godzin wobec $32,6 \%$ kobiet.

${ }^{25}$ Plan działań na rzecz równości kobiet i mężczyzn 2006-2010.

${ }^{26}$ Docelowo udział kobiet na kierowniczych stanowiskach w sektorze publicznym i w sferze badań winien osiagnąc poziom $25 \%$. Na temat potrzeby poszukiwania innowacyjnych rozwiązań w obszarze polityki społecznej patrz: M. Grewiński, Nowe wyzwania i paradygmaty w polityce społecznej - w poszukiwaniu innowacyjnych rozwiqzań, w: Europejskie innowacje. Teoria i praktyka, red. J. Babiak, T. Baczko, Warszawa-Bruksela 2011.

27 A. Zachorowska-Mazurkiewicz, Implikacje nierównego traktowania kobiet i mężczyzn na rynku pracy w Polsce w świetle strategii lizbońskiej, w: Unia Europejska w kontekście strategii lizbońskiej oraz gospodarki i społeczeństwa wiedzy w Polsce, red. E. Okoń-Horodyńska, K. Piech, Instytut Wiedzy i Innowacji, Warszawa 2006.

${ }^{28}$ Sprawozdanie Komisji dla Rady, Parlamentu Europejskiego, Europejskiego Komitetu Ekonomiczno-Społecznego i Komitetu Regionów - Równość kobiet i mężczyzn - rok 2009, Bruksela, dnia 27.02.2009, KOM(2009) 77 wersja ostateczna.
} 
W dalszej części dokumentu zwrócono się w kierunku problemu nadużyć wobec kobiet. Podjęto kwestię różnych form przemocy wobec nich, jako grupy szczególnie narażonej. Podkreślono, iż działania w tym obszarze nakierowane winny być przede wszystkim na prewencję oraz eliminację tradycyjnych i kulturowo zakorzenionych praktyk godzących w godność kobiet i naruszających ich integralność cielesną. Zwrócono uwagę na konieczność bezwzględnego wykorzenienia handlu ludźmi, którego ofiarami padają głównie kobiety i dziewczynki z zagrożonych ubóstwem grup społecznych. Do zintegrowanych działań służących temu celowi zaliczono podejmowanie kroków zapobiegających temu zjawisku, dalszą pracę nad prawodawstwem oraz pomoc i ochronę ofiar podobnych procederów, poprzez podejmowanie działań zmierzających do ułatwienia im dostępu do rynku pracy, szkoleń zawodowych, a także edukacji. Kwestie te reguluje dyrektywa Rady z dnia 29 kwietnia 2009 r. ${ }^{29}$

Ponadto odniesiono się do kwestii walki ze stereotypami na temat płci. Wskazano na problem powielania przez mężczyzn i kobiety tradycyjnych wzorców w zakresie kształcenia i zdobywania kwalifikacji. Zgodnie też z nimi kobiety częściej wybierają mniej cenione i przede wszystkim związane z niższym wynagrodzeniem profesje. Kolejnym niekorzystnym efektem funkcjonowania stereotypów jest zarówno pozioma, jak i pionowa segregacja, której podlegają kobiety w miejscach pracy. Większość z nich jest nadal zatrudniana w sektorach sfeminizowanych i często związanych z niższymi płacami, a w hierarchii zatrudnienia $\mathrm{w}$ dalszym ciagu zajmują niższe stanowiska. Jedna z dróg przeciwdziałania tego typu zjawiskom jest promowanie i ułatwianie kobietom rozpoczynania kariery zawodowej w sektorach dla nich nietypowych, a zarazem zachęcanie mężczyzn do podejmowania pracy w dziedzinach sfeminizowanych. Poruszono także sprawę roli mediów w kreowaniu obrazu obojga płci i niwelowaniu skutków krzywdzących stereotypów, chociażby w kampaniach społecznych. Zaznaczono także, iż wdrażanie i egzekwowanie unijnego prawodawstwa w obszarze równości płci, będzie stanowiło priorytet przyszłych rozszerzeń Wspólnoty. Podkreślono, iż propagowanie równości płci w ramach europejskiej polityki sąsiedztwa, polityki zewnętrznej oraz polityki rozwoju, stanowi dla UE obowiązek. Założono, iż oparciem przy wprowadzaniu w życie działań określonych w Planie będą fundusze strukturalne, programy finansowane z różnych obszarów polityki oraz program PROGRESS. Ten ostatni jest unijnym programem na rzecz zatrudnienia i solidarności społecznej. Obok finansowego wspierania wspólnotowych celów w obszarze zatrudnienia oraz spraw społecznych, obejmuje swym zasięgiem także kwestie równości szans. Jest zintegrowanym programem przewidzianym na lata 2007-2013, który zastapił obowiązujące do 2006 r. cztery programy dotyczące zwalczania dyskryminacji, promowania równouprawnienia kobiet i mężczyzn, środków na rzecz zatrudnienia oraz walki z wykluczeniem społecznym. Zasadniczo nakierowany jest na finansowanie przedsięwzięć w pięciu następujących obszarach:

- zatrudnienie;

— integracja społeczna i ochrona socjalna;

- warunki pracy;

— walka z dyskryminacją;

- równość kobiet i mężczyzn ${ }^{30}$.

${ }^{29}$ Dyrektywa Rady 2004/81/WE z dnia 29 kwietnia 2004 r. w sprawie dokumentu pobytowego wydawanego obywatelom państw trzecich, którzy sq ofiarami handlu ludźmi lub podlegali działaniom ułatwiajacym nielegalna imigrację, którzy wspótpracuja z właściwymi władzami (Dz. U. UE L 261 z 6.08.2004, s. 19).

${ }^{30} \mathrm{http}$ ://ec.europa.eu/index_pl.htm, z dnia 19.07.2011. 
W marcu 2006 r. doszło także do podpisania Europejskiego Paktu na Rzecz Równości $\mathrm{Płci}^{31}$, który stanowi wyraz zaangażowania najwyższego szczebla przedstawicieli państw członkowskich we współpracę z Komisją w celu osiagnnięcia równego traktowania bez względu na płeć. Do głównych dziedzin wymagających podjęcia działań zaliczono:

- niwelowanie wszelkich dysproporcji oraz stereotypów związanych z płcią funkcjonujących na rynku pracy;

— propagowanie większej równowagi między życiem osobistym i zawodowym niezależnie od płci;

— umacnianie sprzyjającego ładu instytucjonalnego poprzez uwzględnianie problematyki płci oraz ściślejszy w tym zakresie nadzór.

W Pakcie w każdym z tych obszarów wyznaczono szczegółowsze metody pracy na rzecz ich osiagnięcia. W 2006 r. powołano ponadto odrębną agendę UE, tj. Europejski Instytut ds. Równości Meżczyzn i Kobiet ${ }^{32}$, której za cel główny postawiono opracowanie jednolitego systemu gromadzenia i analizowania danych nt. równości kobiet i meżczyzn, dzięki czemu informacje pochodzące z różnych krajów mogłyby być porównywane, co ostatecznie umożliwia ocenę zjawiska w skali Europy. Do jego zadań należy również wspieranie włączania problematyki równości płci do wszystkich polityk, czemu slużyć mają wypracowane przez Instytut metody. Agenda ta ma także stanowić swego rodzaju forum wymiany sprawdzonych rozwiazań i dobrych praktyk między zainteresowanymi stronami. Nakierowana jest ponadto na działania związane ze zwiększaniem świadomości oraz uwrażliwianie społeczeństwa na problematykę równości kobiet i mężczyzn ${ }^{33}$.

Kontynuacją Planu działań na rzecz równości kobiet i mężczyzn 2006-2010 jest zatwierdzona przez Komisję Europejską 23 września 2010 r. nowa Strategia na rzecz równości kobiet $i$ mężczyzn 2010-2015 $5^{34}$. W dokumencie ustanowiono sześć obszarów priorytetowych, które zasadniczo są tożsame z tymi zaproponowanymi w marcu 2010 r., które stanowić miały podstawę Europejskiej Karty Praw Kobiet ${ }^{35}$. Zaliczono do nich następujące dziedziny:

— równa niezależność ekonomiczna;

- równa praca za tę samą płacę i praca równej wartości;

— równość w procesach decyzyjnych;

— godność, integralność i eliminacja przemocy uwarunkowanej płcią;

— równość płci w polityce zewnętrznej;

— kwestie horyzontalne.

${ }^{31}$ Pakt stanowi załącznik II do dokumentu Konkluzje prezydencji-23-24 marca 2006 r., Bruksela, 18 maja 2006 r., 7775/1/06 REV 1.

${ }^{32}$ Sprawozdanie dotyczące ustanowienia Europejskiego Instytutu ds. Równości Kobiet i Mężczyzn Parlament Europejski przyjął w grudniu 2006 r., jednak sama jego idea narodziła się znacznie wcześniej, bo w 1995 r. Inicjatorem przedsięwzięcia było Szwedzkie Ministerstwo ds. Równości Mężczyzn i Kobiet, które w 1999 r. w trakcie seminarium w Sztokholmie przedłożyło wstępny jego projekt. Siedzibom unijnej agendy jest Wilno.

${ }^{33} \mathrm{http} / /$ ec.europa.eu/index_pl.htm, z dnia 19.07.2011.

${ }^{34}$ Komunikat Komisji do Parlamentu Europejskiego, Rady, Europejskiego Komitetu Ekonomiczno-Społecznego i Komitetu Regionów, Strategia na rzecz równości kobiet i mężczyzn 2010-2015, Bruksela, dnia 21 września 2010 , KOM(2010) 491 wersja ostateczna.

${ }^{35}$ Celem skuteczniejszego egzekwowania praw kobiet, za jak najszybszym opracowaniem Europejskiej Karty Praw Kobiet opowiadali się przede wszystkim posłowie z Komisji Praw Kobiet i Równouprawnienia. Stanowiąca polityczną deklarację Karta została opublikowana przez Komisję Europejską w marcu 2010 r. 


\section{Sytuacja kobiet na europejskim rynku pracy}

Progres we wdrażaniu założeń polityki na rzecz równości kobiet i mężczyzn jest na poziomie unijnym ustawicznie monitorowany. Corocznie Komisja Europejska, na wniosek Rady Europejskiej składa sprawozdanie, w którym oprócz poczynionych postępów, odnosi się także do przyszłych wyzwań oraz priorytetów dalszej działalności w tym obszarze. W raporcie z grudnia 2009 r. wskazano, iż w rozwoju społeczeństwa oraz rynku pracy obserwuje się wyraźną, pozytywną tendencję w kwestii równości kobiet i mężczyzn, niemniej jednak nierówności płci nadal się utrzymują we wszystkich sferach życia społecznego i to głównie na niekorzyść kobiet. Postępy w tym obszarze wymagają skoordynowanych działań na wielu płaszczyznach, gdyż zdeterminowane są zmianami zarówno strukturalnymi, jak i na poziomie postaw oraz nowych definicji ról kobiet i mężczyzn. W obszarze zatrudnienia nierówność płci przejawia się w odmiennym traktowaniu kobiet i mężczyzn, a dokładniej w różnicy w stopie zatrudnienia, poziomie płac, liczbie godzin pracy, czy też zajmowaniu odpowiedzialnych stanowisk. Niewątpliwie jako korzystny należy odnotować rosnący udział kobiet w rynku pracy, a tym samym wzrost ich wkładu we wzrost gospodarczy w Unii Europejskiej. Wedle danych OECD od 1995 r. równy jest on jednej czwartej rocznego wzrostu gospodarczego. Pozytywne zmiany dokonały się w obszarze poziomu zatrudnienia kobiet. W latach 1998-2008 stopa ich zatrudnienia wzrosła o 7,1 punktów procentowych sięgając w $2008 \mathrm{r}$. pułapu 59,1\%. Warto tutaj zaznaczyć, iż jest to poziom bliski docelowego, tj. 60\%, jaki został założony w Strategii Lizbońskiej. Niemniej jednak trzeba mieć na uwadze występujące w tym względzie istotne różnice na poziomie państw członkowskich ${ }^{36}$. Rozpiętość tego wskaźnika waha się w zależności od kraju od poniżej $40 \%$ do ponad 70\%. Najogólniej jednak ujmując, średnia różnica między stopą zatrudnienia kobiet i mężczyzn zmniejszyła się z 18,2 punktów procentowych w r. 1998 do 13,47 punktów w 2008 r. $^{37}$

Jak wynika ze sprawozdania, te niewątpliwie pozytywne tendencje zostały poważnie zaburzone w wyniku kryzysu gospodarczego. W początkowym jego okresie, tj. na przełomie lat 2008-2009 stopa bezrobocia w UE w szybszym tempie rosła w przypadku mężczyzn ${ }^{38}$. Poczynając jednak od ostatniego kwartału 2009 r., tempo wzrostu stopy bezrobocia obojga płci zrównało się, co prawdopodobnie stanowiło wyraz rozszerzenia się kryzysu na sektory bardziej zróżnicowane pod względem płci niż te, które zostały nim dotknięte w początkowym etapie jego trwania ${ }^{39}$. Należy także mieć na uwadze, iż kobiety częściej są pracownikami sfery budżetowej niż mężczyźni, przez co są w większym stopniu narażone na zwolnienia związane z cięciami budżetowymi. Raport wskazuje również na fakt, iż uwzględniając doświadczenia przeszłych kryzysów można zauważyć, iż zatrudnienie mężczyzn wraca do poprzedniego poziomu szybciej niż zatrudnienie kobiet. Co więcej, wśród osób, które utraciły pracę, to kobiety są obciążone wyższym ryzykiem nie znalezienia nowego zatrudnienia. Niepokojące jest ponadto, iż wśród osób nieaktywnych zawodowo lub częściowo bezrobotnych

\footnotetext{
${ }^{36}$ Patrz szerzej: G. Węgrzyn, Kobiety na europejskim rynku pracy, w: Bezrobocie we współczesnych gospodarkach rynkowych, red. D. Kopycińska, Wydawnictwo Uniwersytetu Szczecińskiego, Szczecin 2006.

${ }^{37}$ Sprawozdanie Komisji dla Rady, Parlamentu Europejskiego, Europejskiego Komitetu Ekonomiczno-Społecznego i Komitetu Regionów - Równość kobiet i mężczyzn - rok 2010, Bruksela, dnia 18.12.2009, KOM(2009) 694 wersja ostateczna.

${ }^{38}$ Od maja 2008 r. do września 2009 r. stopa bezrobocia w przypadku mężczyzn wzrosła z 6,4\% do 9,3\%, w tym samym czasie analizowany wskaźnik w odniesieniu do kobiet zmienił się z 7,4\% do 9\%.

${ }^{39} \mathrm{~W}$ pierwszym okresie kryzysu, najbardziej ucierpiały zdominowane przez mężczyzn sektory: przemysłowy i budowlany.
} 
(pracujących w mniejszym wymiarze czasu pracy niż by chciały), zdecydowaną większość stanowią kobiety $^{40}$. Kolejną specyfiką zatrudnienia kobiet jest fakt, iż są one bardziej narażone na znalezienie się w niekorzystnej sytuacji na rynku pracy, co jest związane np. z zawieraniem umów na niepewnych warunkach, czy też pracą w niedobrowolnym, niepełnym wymiarze czasu pracy, a nade wszystko z nadal utrzymującą się różnicą w poziomie wynagrodzenia (średnio w 2007 r. w UE różnica ta sięgała 17,6\%). Taka sytuacja ma nie tylko odzwierciedlenie $\mathrm{w}$ aktualnych dochodach, ale także pociąga za sobą konsekwencje długoterminowe, tj. niższą w przyszłości emeryturę i związane z tym ryzyko ubóstwa ${ }^{41}$. Jak zauważono w sprawozdaniu, kwestie równości płci, należy rozpatrywać nie w kategoriach kosztów związanych z wdrażaniem rozwiązań w tym obszarze, lecz wyzwań długoterminowych, przynoszących efekty odroczone, nader istotne w dhugofalowej perspektywie wzrostu gospodarczego. W tym względzie trzeba mieć także na uwadze problem starzejącego się społeczeństwa oraz związane z tym spodziewane niedobory w liczbie pracowników wysoko wykwalifikowanych. Do determinant tych zjawisk zaliczyć należy również podejmowane często przez młodych ludzi decyzje o nieposiadaniu lub też posiadaniu mniejszej liczby dzieci, czego źródeł można upatrywać w braku równowagi między życiem prywatnym i zawodowym. Ważną kwestią jest, iż w krajach stwarzających korzystne warunki w zakresie opieki nad dziećmi, urlopów rodzicielskich oraz elastycznych form pracy, wyższe są zarówno stopa zatrudnienia kobiet, jak i wskaźniki urodzeń ${ }^{42}$.

Odnotowano, iż mimo, że kobiety stanową większość absolwentów szkół wyższych i to we wszystkich dziedzinach ${ }^{43}$, to jednak nadal częściej zatrudniane są w sfeminizowanych i zarazem często gorzej wynagradzanych sektorach, a ponadto zajmują stanowiska mniej odpowiedzialne i to we wszystkich sferach życia społecznego. Źródeł ich niekorzystnej sytuacji na rynku pracy należy również szukać w systemach polityki społecznej. Niewątpliwie brak dostępu do usług z zakresu opieki nad dziećmi, osobami starszymi i niepełnosprawnymi, a także optymalnych systemów urlopowych czy też elastycznych form zatrudnienia dla obojga rodziców, stanowi często dla kobiet barierę zarówno w kwestiach uczestnictwa w rynku pracy, jak i podjęcia pracy w pełnym wymiarze godzin ${ }^{44}$. Obserwuje się ponadto, iż kobiety posiadające dzieci pracują mniej niż kobiety bezdzietne (stopa zatrudnienia jest dla nich niższa o 11,5 punktów procentowych), natomiast w przypadku mężczyzn tendencja ta jest odwrotna (stopa zatrudnienia ojców jest wyższa o 6,8 punktów niż mężczyzn bez dzieci). Tak wyraźnie zarysowany i zarazem silny wpływ rodzicielstwa na uczestnictwo w rynku pracy jest uwarunkowany wielopłaszczyznowo, a nade wszystko wiąże się z tradycyjnym postrzeganiem ról kobiet i mężczyzn oraz brakiem w wielu państwach członkowskich placówek zajmujących się opieką nad dziećmi. W kontekście starzejącego się społeczeństwa, kwestią stanowiącą wyzwanie jest konieczność opieki nad osobami jej potrzebującymi ${ }^{45}$.

\footnotetext{
${ }^{40}$ Ponad dwie trzecie spośród 63 mln osób nieaktywnych zawodowo w wieku 25-64 lat w UE, stanowią kobiety. Trzeba też pamiętać, iż nie wszystkie osoby bezrobotne są jako takie zarejestrowane.

${ }^{41}$ Wskaźnik zagrożenia ubóstwem w 2007 r. był wyższy w przypadku kobiet, sięgając poziomu 17\% (dla mężczyzn 15\%). Różnica ta była tym wyraźniejsza im osoby były starsze, wówczas dla kobiet wzrastał do $22 \%$ wobec $17 \%$ dla mężczyzn. Grupą ryzyka jak się okazało są również rodzice samotnie wychowujący dzieci, dla których wskaźnik ten wyniósł aż 34\%.

${ }^{42}$ Równość kobiet i mężczyzn - rok 2010.

${ }^{43}$ W 2006 r. wśród absolwentów szkół wyższych w UE, 59\% stanowiły kobiety.

${ }^{44}$ W 2008 r. w niepełnym wymiarze czasu pracy pracowało 31,1\% kobiet wobec 7,9\% mężczyzn.

${ }^{45}$ W 2005 r. obowiązki opieki nad osobami dorosłymi jej wymagającymi, miało 20 mln osób w wieku 15-64 lat, z czego 12,8 mln stanowiły kobiety a 7,6 mln to mężczyźni.
} 
Pozytywne zmiany w obszarze rynku pracy kobiet obserwuje się w odniesieniu do ich uczestnictwa w procesach decyzyjnych. Wzrosła w UE liczba kobiet wyznaczanych na stanowiska decyzyjne. Niemniej jednak w sferze gospodarczej i politycznej, nadal dominują mężczyźni. Uśredniając, zaledwie jeden na czterech członków parlamentów narodowych i ważniejszych ministrów rządów krajowych, to kobieta, choć należy zaznaczyć, iż w tym względzie państwa członkowskie są zróżnicowane. Na poziomie instytucji unijnych poprawę przyniosły wybory do Parlamentu Europejskiego z 2009 r., w wyniku których udział kobiet wzrósł z 31\% do 35\%. W obszarze gospodarczym sytuacja ta wygląda już jednak gorzej. Kobiety stanowią zaledwie jedną dziesiątą członków zarządów najistotniejszych europejskich przedsiębiorstw oraz 3\% wśród prezesów zarządów ${ }^{46}$.

$\mathrm{Na}$ fakt $\mathrm{w}$ dalszym ciągu utrzymujących się różnic w traktowaniu kobiet i mężczyzn w różnych dziedzinach życia społecznego, w tym na rynku pracy, wskazują wyniki badań przeprowadzonych przez Eurobarometr ${ }^{47}$. Ogólnie istniejący brak równości między płciami, jako zjawisko często występujące, zostało ocenione przez 43\% Polaków i aż 62\% Europejczyków. Na pytanie o obszar wyraźnych nierówności między płciami, w którym działania powinny zostać podjęte w pierwszej kolejności, na drugim miejscu znalazła się luka płacowa między kobietami a mężczyznami. Takiej odpowiedzi udzieliło 50\% badanych pochodzących z UE, wśród polskich respondentów natomiast odsetek ten wyniósł 39\%. Ponadto 27\% Polaków i $38 \%$ obywateli Wspólnoty oceniło tę kwestię jako wymagającą podjęcia bardzo pilnych działań zmierzających do zniwelowania 17\% różnicy płacowej i odpowiednio 48\% i 44\% uznało tę sprawę jako raczej pilną. Ankietowani uznali również, że seksistowskie stereotypy ${ }^{48}$ najczęściej spotykane są właśnie w życiu zawodowym. Na taką odpowiedź wskazało 54\% obywateli Wspólnoty i 35\% badanych pochodzących z Polski. Ze stwierdzeniem, iż dla kobiety ważne jest by miała swoje własne zarobki, zgodziło się $87 \%$ badanych z Polski i $81 \%$ Europejczyków $^{49}$. Do głównych obszarów wymagających podjęcia działań celem zwiększenia udziału kobiet $\mathrm{w}$ rynku pracy respondenci zaliczyli zrównanie ich zarobków z tymi uzyskiwanymi przez mężczyzn za taką samą pracę przy założeniu posiadania takich samych umiejętności (36\% i 44\%), zwiększenie liczby miejsc opieki nad dziećmi oraz osobami jej wymagającymi (40\% i 41\%) oraz wprowadzenie bardziej elastycznych godzin pracy $(30 \%$ i 40\%). Jednocześnie za bariery wpływające na mniejszą liczbę kobiet zajmujących odpowiedzialne stanowiska, uznano fakt, iż kobiety ze względu na swoje obowiązki rodzinne mają mniejszą swobodę ( $82 \%$ i 76\%) oraz dominację w środowisku biznesowym mężczyzn, którzy nie mają dostatecznego zaufania do kobiet (71\% i 74\%). Jako pozytywne należy zaznaczyć, iż poprawę sytuacji w obszarze niwelowania nierówności płci w porównaniu do sytuacji sprzed 10 lat, widzi aż 66\% badanych Polaków i 64\% Europejczyków. Można też skonstatować, iż zasadniczo wyniki przeprowadzonych przez Eurobarometr badań są zbieżne z wnioskami formułowanymi w oparciu o dane statystyczne ${ }^{50}$.

${ }^{46}$ Równość kobiet i mężczyzn - rok 2010.

${ }^{47}$ Badanie Równość płci w UE w 2009 r. zostało przeprowadzone w dniach 11.09-5.10.2009 r. na próbie 26663 obywateli Unii Europejskiej (UE 27), w Polsce natomiast wzięło w nim udział 1000 osób przebadanych w dniach 12-28.09.2009 r.

${ }^{48}$ Stereotypy seksistowskie zdefiniowano jako obiegowe stwierdzenia/powiedzenia, które czasami słyszy się na temat mężczyzn i kobiet, będące przyczyną wielu nierówności.

${ }^{49}$ Wśród Polaków 43\% badanych wskazało, że całkowicie się zgadają i 44\%, że raczej się zgadają. Dla obywateli UE odsetek poszczególnych odpowiedzi wynosił odpowiednio: $41 \%$ i $40 \%$.

${ }^{50}$ Eurobarometr, Równość plci w UE w $2009 \mathrm{r}$. 
W pierwszym okresie funkcjonowania Unii Europejskiej sprawa równego traktowania kobiet i mężczyzn ograniczała się zasadniczo do przepisów związanych z dyskryminacją i polityką antydyskryminacyją. Szczegółowe kwestie w obszarze równouprawnienia kobiet i mężczyzn były podejmowane stopniowo i od lat 70 . XX w. - ustawicznie wprowadzano w tym zakresie kolejne rozwiązania. Obecnie problemy związane z pozycją kobiet na rynku pracy są postrzegane jako ważny obszar polityki społecznej, w którym upatruje się źródeł niewykorzystywanego potencjału wpływającego na wzrost gospodarczy. Ponadto niewątpliwie w sposobie traktowania kobiet i mężczyzn na rynku pracy, w dalszym ciągu istnieje trudna do zlikwidowania nierównowaga, która pomimo wyraźnych postępów w tej dziedzinie, nadal wymaga podejmowania wzmożonych działań.

\section{Summary}

\section{The Position of Women on the Labor Market in the Light of EU Regulations}

The position of women on the European labor market continues to be unstable. In order to make the opportunities for both genders equal at the EU level, appropriate regulations have been adopted since its beginnings. The first regulations focused on the issue of discrimination, aiming at a policy of anti-discrimination. The range of regulations in this area has gradually expanded to become an important part of EU policy. Any improvement in the situation is assessed in terms of increased competitiveness, innovativeness and economic growth. EU regulations and programs to promote gender equality, including those aimed at improving the situation of women on the labor market have now become a significant field of the Community's activities. Progress there is already noticeable, although it continues to call for further commitment and cooperation on many levels. 
